\title{
Chapter 4 Thermochemical Conversion of Rice Straw
}

\author{
Monet Concepcion Maguyon-Detras, Maria Victoria P. Migo, \\ Nguyen Van Hung, and Martin Gummert
}

\begin{abstract}
Biomass conversion into various forms of energy, such as heat, power, or biofuels using thermal processes, involves the decomposition of biomass by exposure to heat, typically above $300{ }^{\circ} \mathrm{C}$. Thermal conversion processes include pyrolysis, gasification, and direct combustion. Several factors affect the yields and energy recovery from these processes including temperature, reaction time, heating rate, absence, or presence of oxygen, use of catalysts, and pressure. Due to rice straw's relatively high carbon and hydrogen contents, it contains a considerable amount of energy that make it a suitable feedstock for thermal conversion. In this chapter, the basic principles and factors affecting the thermal conversion of biomass into energy are discussed. Studies on the use of rice straw as feedstock to produce heat, power, and biofuels via thermal conversion are reviewed. Utilization of thermal conversion byproducts including biochar and ash will are presented. Thermal processes are compared in terms of energy conversion, possible environmental impacts, and technological and commercial maturity.
\end{abstract}

Keywords Bioenergy · Pyrolysis · Gasification · Combustion · Biomass · Thermochemical conversion

M. C. Maguyon-Detras $(\bowtie) \cdot$ M. V. P. Migo

Department of Chemical Engineering, College of Engineering and Agro-Industrial

Technology, University of the Philippines Los Baños (UPLB),

Los Baños, Laguna, Philippines

e-mail: mmdetras@up.edu.ph; mpmigo@up.edu.ph

N. V. Hung $\cdot$ M. Gummert

International Rice Research Institute (IRRI), Los Baños, Laguna, Philippines

e-mail: hung.nguyen@irri.org; m.gummert@irri.org 


\subsection{Overview of Thermal Conversion Processes}

Biomass conversion by thermal processes (i.e., direct combustion, gasification, pyrolysis) involves the decomposition of biomass into various solid, liquid, and gaseous components by exposure to heat (normally above $300{ }^{\circ} \mathrm{C}$ ). Different process conditions, such as temperature, reaction time, heating rate, absence or presence of oxygen, use of catalysts, and pressure, affect the distribution and quality of the products generated (Capareda 2014; Maguyon and Capareda 2013; MaguyonDetras and Capareda 2017). Table 4.1 shows the typical process conditions and products for thermal conversion processes.

Pyrolysis is the thermal conversion of biomass at temperatures typically below $600{ }^{\circ} \mathrm{C}$ in the complete absence of oxygen to produce higher-energy density materials including char, bio-oil, and gaseous products. Gasification usually occurs at temperatures greater than $600{ }^{\circ} \mathrm{C}$ with an oxygen supply that is only a fraction of what is theoretically required for complete combustion. The resulting gaseous product, which typically consists of hydrogen, carbon monoxide, methane, carbon dioxide and nitrogen, is said to be more versatile than the original feedstock and can be burned to produce process heat and steam or be used in gas turbines to produce electricity (Demirbas 2001). Combustion is the oldest method of thermal conversion of biomass, which accounts for almost $97 \%$ of the world's bioenergy production (Demirbas et al. 2009). In this process, the feedstock is subjected to high temperatures (typically above $700{ }^{\circ} \mathrm{C}$ ) with an excess amount of air to produce gaseous products consisting mainly of $\mathrm{CO}_{2}, \mathrm{H}_{2} \mathrm{O}, \mathrm{N}_{2}$, and heat.

Pyrolysis serves as the core reaction of thermal conversion processes since the irreversible degradation of the biomass starts at temperatures of about $150-200{ }^{\circ} \mathrm{C}$ with the absence of oxygen. According to Pollex et al. (2011), even if the feedstock is surrounded by oxygen from the air, it does not participate in the reaction since the pyrolysis gases produced during this process flow out from the biomass particles and prevent oxygen from reaching it. As the temperature goes up and some oxygen (less

Table 4.1 Overview of thermal conversion processes, their process conditions and products

\begin{tabular}{|c|c|c|c|}
\hline & Pyrolysis & Gasification & Combustion \\
\hline \multicolumn{4}{|c|}{ Process conditions } \\
\hline $\begin{array}{l}\text { Temperature } \\
\left({ }^{\circ} \mathrm{C}\right)\end{array}$ & $300-600$ & $>600$ & $>700$ \\
\hline Reaction time & $\begin{array}{l}1 \mathrm{~s} \text { (fast pyrolysis) days (slow } \\
\text { pyrolysis) }\end{array}$ & $\begin{array}{l}\text { Several seconds to } \\
\text { minutes }\end{array}$ & - \\
\hline Air supply, $\lambda^{\mathrm{a}}$ & $\lambda=0$ & $\lambda=0.2-0.5$ & $\lambda \geq 1$ \\
\hline \multicolumn{4}{|l|}{ Products } \\
\hline $\begin{array}{l}\text { Gaseous } \\
\text { product }\end{array}$ & $\begin{array}{l}\mathrm{CO}, \mathrm{CH}_{4}, \mathrm{C}_{\mathrm{X}} \mathrm{H}_{\mathrm{Y}}, \mathrm{CO}_{2}, \mathrm{H}_{2} \mathrm{O}, \\
\text { pyrolysis oils, } \mathrm{N} \text { - and } \mathrm{S}- \\
\text { containing compounds }\end{array}$ & $\begin{array}{l}\mathrm{CO}, \mathrm{H}_{2}, \mathrm{CO}_{2}, \mathrm{H}_{2} \mathrm{O}, \mathrm{CH}_{4}, \\
\mathrm{C}_{\mathrm{X}} \mathrm{H}_{\mathrm{Y}} \text {, tars, } \mathrm{NH}_{\mathrm{y}}, \mathrm{NO}_{\mathrm{x}}, \\
\mathrm{H}_{2} \mathrm{~S}, \mathrm{COS}\end{array}$ & $\begin{array}{l}\mathrm{CO}_{2}, \mathrm{H}_{2} \mathrm{O}, \mathrm{CO}, \\
\mathrm{C}_{\mathrm{X}} \mathrm{H}_{\mathrm{Y}}, \mathrm{NO}_{\mathrm{X}}, \mathrm{SO}_{\mathrm{X}}\end{array}$ \\
\hline Solid & $\mathrm{C}_{\mathrm{m}} \mathrm{H}_{\mathrm{n}} \mathrm{O}_{\mathrm{k}}(\mathrm{N}, \mathrm{S})$, ash & $\mathrm{C},(\mathrm{N}, \mathrm{S})$, ash & Ash, $(\mathrm{N}, \mathrm{S})$ \\
\hline
\end{tabular}

Source: Adapted from Capareda (2014) and Lohri et al. (2015)

$\mathrm{a} \lambda=\mathrm{O}_{2}$ supplied $/ \mathrm{O}_{2}$ theoretical 
than the theoretical oxygen) is introduced, the process shifts to gasification. Any further increases in temperature and oxygen supply lead to combustion reactions.

The composition of the products produced during thermal conversion depends on the severity of process conditions and oxygen supply. Thermal processes tend to shift the biomass components into different materials in terms of their carbon, hydrogen, and oxygen contents. Slow pyrolysis, for example, tends to increase the carbon content of the feedstock producing char, while rapid or fast pyrolysis produces more hydrocarbons. Oxidation, on the other hand, produces gaseous products, such as $\mathrm{CO}_{2}$ and $\mathrm{H}_{2} \mathrm{O}$. Steam and hydrogasification tend to produce gaseous products enriched with hydrogen.

\subsection{Properties of Rice Straw for Thermal Conversion}

Biomass properties and chemical composition are important in determining a material's suitability for thermal conversion. Chapter 1 presented rice straw properties and composition. The moisture content of the biomass is one of the characteristics initially considered and is an important criterion in selecting the appropriate technology for conversion. Biomass feedstocks with moisture contents usually above 60 to $65 \%$, by weight, have very low calorific values to be considered for combustion. Hence, biogas production is more feasible if drying is not considered (IFC 2017). For gasification, moisture contents of about 50 and $60 \%$, by weight, can be handled using updraft bed gasifiers and fluidized bed gasifiers, respectively (Roos 2009). For pyrolysis, the moisture content of the biomass should be below 20-25\% (Dong et al. 2016). Some reactor designs, however, may be amenable to higher moisture contents such as the multi-sectional rotary kilns used for pyrolysis of wastes with high organic content (Chen et al. 2015). As mentioned in Chap. 1, however, rice straw moisture content widely varies depending on the handling, collection and storage methods, and duration.

Physical properties such as particle size, specific heat capacity, and thermal conductivity of the biomass, on the other hand, affect the rate at which heat and oxygen penetrates the biomass particles during thermal processing. Particle size or particle size distribution (PSD) is the measure of the physical dimensions of the biomass material and can be obtained using various standard sieves. Biomass materials (i.e., agricultural residues) vary in sizes and need to be ground to less than $10 \mathrm{~mm}$ in size for various conversion processes (Capareda 2014). Loose rice straw is typically long and needs to be chopped into smaller pieces. To do so, an additional chopper or shredder is needed, entailing additional energy input for the process. Particle size is particularly important in the pyrolysis process for it can control the rate of heat transfer in the biomass, making it a major factor in the rate of drying and primary pyrolysis reaction (Tripathi et al. 2016; Isahak et al. 2012; Demirbas 2004). Specific heat capacity is defined as the ratio of the amount of heat energy transferred to or from the material to the resulting increase in temperature of this material per unit

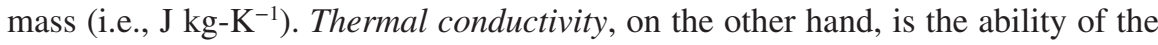


material to conduct or transfer heat (expressed in $\mathrm{W} \mathrm{m}-\mathrm{K}^{-1}$ ) (Capareda 2014). According to Czernik (2010), biomass with large particle size has low thermal conductivity that results in slow heat and a mass transfer rate.

The chemical composition of the biomass may be used to evaluate the thermal degradation of the biomass and residues/pollutants (i.e, ash, NOx, SOx), which may be generated. Proximate analysis provides information on the behavior of the feedstock when it is heated (i.e., how much goes off as gas or vapors and how much remains as fixed carbon). It includes the measurement of volatile matter, fixed carbon, and ash. Volatile matter (VM) is the material expelled from the biomass when exposed to $950{ }^{\circ} \mathrm{C}$ for $7 \mathrm{~min}$ in an oxygen-free environment. It includes volatile carbon, combined water, net hydrogen, nitrogen, and sulfur. VM is important in thermal conversion since high amounts lead to more combustible gases during combustion or more gaseous (condensable and non-condensable) products during gasification and pyrolysis.

Fixed carbon (FC) is the material expelled after burning the moisture- and VM-free biomass to $575{ }^{\circ} \mathrm{C}$ for $4 \mathrm{~h}$ until the material becomes grayish white (Capareda 2014). FC fraction in the residual biomass usually increases as volatiles are released during thermal degradation (Maguyon and Capareda 2013). Char, the residue after pyrolysis, has typically high amounts of FC and ash. Ash is the residue which remains after complete combustion of the feedstock which can be used for other purposes such as cement aggregate replacement, fertilizer additive, etc. As can be seen in Table 4.2, rice straw FC widely varies among different samples but the range is comparable with other biomass used for thermal conversion such as rice husk and wheat straw. Volatile content is relatively lower compared to other biomass while ash content is relatively higher. Herbaceous biomass such as rice straw has typically higher ash content (up to $25 \%$ ) compared to woody biomass. This may be attributed to the physiological ash, which results from intrinsic biomass properties such as plant type, maturity and anatomical fractions. High ash contents result in lower energy yields, catalyst impairment, and slag formation during thermal

Table 4.2 Proximate analysis of various biomass

\begin{tabular}{|c|c|c|c|c|}
\hline \multirow[b]{2}{*}{ Biomass } & \multicolumn{3}{|c|}{ Components (\% wt) } & \multirow[b]{2}{*}{ Sources } \\
\hline & Volatiles & Fixed carbon & Ash & \\
\hline Rice straw & $\begin{array}{l}60.55- \\
78.07\end{array}$ & $6.93-16.75$ & $\begin{array}{l}14.11- \\
22.70\end{array}$ & $\begin{array}{l}\text { Migo (2019), Biswas et al. (2017), } \\
\text { Fu et al. (2012) }\end{array}$ \\
\hline Rice husks & 73.41 & 11.44 & 15.14 & Biswas et al. (2017) \\
\hline Corn cob & 91.16 & 6.54 & 2.30 & Biswas et al. (2017) \\
\hline Wheat straw & 83.08 & 10.29 & 6.63 & Biswas et al. (2017) \\
\hline Coffee hulls & 77.50 & 11.00 & 11.5 & Huang et al. 2011 \\
\hline Bamboo leaves & 70.30 & 18.70 & 11.00 & Huang et al. 2011 \\
\hline $\begin{array}{l}\text { Sugarcane } \\
\text { bagasse }\end{array}$ & 87.00 & 4.20 & 8.80 & Huang et al. 2011 \\
\hline Sugarcane peel & 77.30 & 10.10 & 12.60 & Huang et al. 2011 \\
\hline
\end{tabular}


conversion. As such, reducing ash content through washing or leaching may be necessary prior to thermal processing (Kenney et al. 2013).

Ultimate analysis, on the other hand, provides information on the elemental composition of the biomass. It includes carbon, hydrogen, oxygen, nitrogen, sulfur and ash, which can be determined in percent by weight using an elemental analyzer. Results of ultimate analysis can be used to determine the atomic O:C and $\mathrm{H}: \mathrm{C}$ ratios of the biomass and thermal conversion products (i.e., char), which can be plotted in the van Krevelen diagram to determine their suitability as fuel alternatives (McKendry 2002). Table 4.3 shows that rice straw is within the biomass region due to its high oxygen content. Fossil fuels, such as coal, are near the y-axis in the van Krevelen plot due to high carbon and low oxygen contents. During thermal conversion, the hydrogen and oxygen contents are released from the biomass by volatilization or distillation, tending to increase the carbon content of the residual biomass. The char obtained from pyrolysis, for example, contains higher amounts of carbon as compared to the original biomass. In complete combustion, on the other hand, only the ash remains since all the combustible components $(\mathrm{C}, \mathrm{H}, \mathrm{N}, \mathrm{S})$ of the feedstock are converted to gaseous products (i.e., $\mathrm{CO}_{2}, \mathrm{H}_{2} \mathrm{O}$ ). Ultimate analysis also shows the potential formation of nitrogen- and sulfur-containing compounds in the products (i.e., NOx and SOx in the gas emissions; nitrogenous compounds in biooil) (Maguyon and Capareda 2013, Maguyon-Detras and Capareda 2017). High nitrogen and sulfur contents of the biomass may lead to formation of SOx and NOx during combustion, which causes environmental problems (i.e., acid rain). Pyrolytic oil containing high amounts of nitrogenous and sulfur-containing compounds may need upgrading to meet transport fuel standards. As shown in Table 4.3, rice straw contains minimal amounts of nitrogen and sulfur, which are comparable with other biomass.

Another basis for the suitability of biomass for thermal conversion is its heating value. Heating value $(\mathrm{HV})$ or calorific value $(\mathrm{CV})$ measures the energy content of the biomass and can be obtained using a calorimeter. As shown in Table 4.4, the higher heating value (HHV) of rice straw is comparable to other biomass materials, such as rice husks and wheat straw indicating its potential as feedstock for thermal conversion.

Table 4.3 Ultimate analysis of various biomass

\begin{tabular}{l|l|l|l|l|l|l}
\hline $\begin{array}{l}\text { Component }(\% \\
\text { wt) }\end{array}$ & C & H & O & N & S & Sources \\
\hline Rice straw & $45.7-$ & $5.1-$ & $48.3-$ & $0.8-$ & $0.3-$ & Migo (2019), Fu et al. (2012), \\
& 61.4 & 8.5 & 58.1 & 1.4 & 0.4 & Biswas et al. (2017) \\
\hline Corn cob & 54.2 & 8.2 & 44.3 & 2.4 & 0.6 & Biswas et al. (2017) \\
\hline Wheat straw & 54.5 & 7.6 & 63 & 0.6 & 0.6 & Biswas et al. (2017) \\
\hline Woody & 49.1 & 6.1 & 44.3 & 0.4 & 0 & Huang et al. (2011) \\
\hline Herbaceous & 47.8 & 6.1 & 45.3 & 0.8 & 0.1 & Huang et al. (2011) \\
\hline Ag. residue & 46.8 & 6 & 45.7 & 0.8 & 0.2 & Huang et al. (2011)
\end{tabular}


Table 4.4 Energy content of various biomass

\begin{tabular}{l|l|l}
\hline Biomass & HHV $\left(\mathrm{MJ} \mathrm{kg}^{-1}\right)$ & Sources \\
\hline Rice straw & $14.2-14.9$ & $\begin{array}{l}\text { Nam et al. (2015), Park et al. (2014), Biswas } \\
\text { et al. (2017) }\end{array}$ \\
\hline Rice husks & 12.9 & Biswas et al. (2017) \\
\hline Corn cob & 16.0 & Biswas et al. (2017) \\
\hline Wheat straw & 14.7 & Biswas et al. (2017) \\
\hline Sawdust & 18.4 & Liu et al. (2013) \\
\hline Cassava stalk & 17.6 & Pattiya (2011) \\
\hline Pine wood chips & 20.2 & Srinivasan et al. (2012) \\
\hline Sewage sludge & 11.4 & Abrego et al. (2013) \\
\hline
\end{tabular}

\subsection{Currently Developed Technologies and Practices of Rice Straw Thermal Conversion}

Figure 4.1 shows the various routes for bioenergy production in the form of heat, steam, biofuels, or power from rice straw via thermal conversion methods and the potential high-value nonenergy byproducts.

\subsubsection{Pyrolysis}

Pyrolysis is an irreversible thermal conversion process done at temperatures typically above $300{ }^{\circ} \mathrm{C}$ in the complete absence of an oxidant. This process, also known as destructive distillation, degrades biomass components into three primary products: char, bio-oil, and synthesis or producer gas (Bridgwater 2006; Capareda 2014). Several reaction parameters (i.e., temperature, heating rate, residence time, pressure, and catalyst) and biomass type and characteristics (i.e., particle size) greatly affect the proportion and quality of the pyrolysis products (Mahinpey et al. 2009). Table 4.5 shows the process parameters and product yields for various pyrolysis modes including gasification. Generally, more char is obtained at lower temperatures while higher amounts of syngas are produced at higher temperatures due to a higher degree of devolatilization and cracking. The liquid product or bio-oil produced in higher amounts at $500-550{ }^{\circ} \mathrm{C}$ may contain various chemicals ranging from aliphatic compounds, acids, alcohols, esters, and nitrogenous compounds (i.e., amines, nitriles) (Chen et al. 2015; Maguyon and Capareda 2013; Maguyon-Detras and Capareda 2017). As shown in Fig. 4.1, all pyrolysis products can be used as fuel.

Char produced from pyrolysis has properties very similar to natural coal and it contains relatively higher energy than the raw biomass (Tag et al. 2016). Bio-oil, on the other hand, has a typically complex composition, high moisture content, and high acidity, hence, physical and chemical upgrading (i.e., column chromatography, distillation, solvent extraction, hydrogenation, and deoxygenation) must be done prior to its application as liquid fuels (i.e., diesel, gasoline) (Teella et al. 2011; Wang 


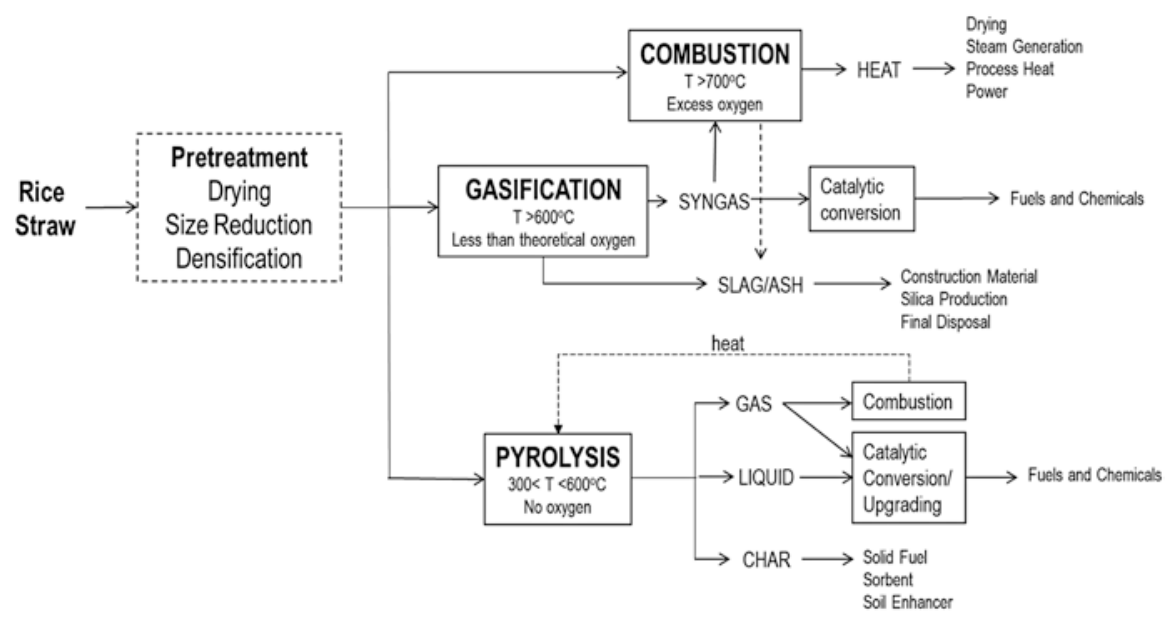

Fig. 4.1 Routes for thermal conversion of rice straw

Table 4.5 Thermal conversion processes, process conditions, and product distribution

\begin{tabular}{l|l|l|l|l|l}
\hline \multirow{2}{*}{ Mode } & Process conditions & \multicolumn{3}{l|}{ Product distribution (\%) } \\
\cline { 2 - 6 } & Peak temperature & Vapor residence time & Char & Liquid & Gas \\
\hline Slow & $\begin{array}{l}\text { Moderate } \\
\left(\sim 500^{\circ} \mathrm{C}\right)\end{array}$ & Long $(5-30 \mathrm{~min})$ & $35 \%$ & $30 \%(70 \%$ water $)$ & $35 \%$ \\
\hline Intermediate & $\begin{array}{l}\text { Moderate } \\
\left(\sim 500^{\circ} \mathrm{C}\right)\end{array}$ & $\begin{array}{l}\text { Moderate } \\
(10-20 \mathrm{sec})\end{array}$ & $\begin{array}{l}20- \\
25 \%\end{array}$ & $50 \%(50 \%$ water $)$ & $\begin{array}{l}25- \\
30 \%\end{array}$ \\
\hline Fast & $\begin{array}{l}\text { Moderate } \\
\left(\sim 500^{\circ} \mathrm{C}\right)\end{array}$ & Short $(<2 \mathrm{sec})$ & $12 \%$ & $75 \%(25 \%$ water $)$ & $13 \%$ \\
\hline Gasification & High $\left(>800{ }^{\circ} \mathrm{C}\right)$ & $\begin{array}{l}\text { Moderate } \\
(10-20 \mathrm{sec})\end{array}$ & $10 \%$ & $\begin{array}{l}5 \% \text { tar }(55 \% \\
\text { water })\end{array}$ & $85 \%$ \\
\hline
\end{tabular}

Sources: Adapted from Bridgwater (2012) and Duku et al. (2011)

et al. 2009, 2011; Cao et al. 2010; Zeng et al. 2011; Amen-Chen et al. 1997; Lu et al. 2011) or for other energy conversions. Syngas, which consists of combustible gases (i.e., methane, hydrogen, carbon monoxide) along with carbon dioxide and nitrogen, is typically recirculated back to the pyrolysis process to supply its heat requirement making the process self-sustaining (Agarwal 2014). According to Chen et al. (2015), energy is produced in a cleaner way via pyrolysis compared to combustion and gasification due to the inert environment producing less NOx and SOx. Also, the syngas produced can be washed before combustion. Pyrolysis systems can also be installed anywhere since their products (bio-oil, char) can be stored and transported making it more flexible than other thermal processes (Agarwal 2014).

Pyrolysis systems generally include facilities for biomass pretreatment (i.e., drying, size reduction), hopper and feeder, pyrolysis reactor, char separation system (i.e., cyclones), and a quenching system for the separation of condensable gases (liquid product) and noncondensable gases (gaseous product). Various reactor 
configurations can be used for biomass pyrolysis such as rotary kilns, fluidized bed, fixed bed, entrained flow, and tubular reactors. Pyrolysis systems can also be combined with other thermal conversion technologies (Chen et al. 2015).

Data and experience on rice straw pyrolysis are mostly from laboratory-scale experiments. There are limited studies reported on bio-oil production in a bench- or pilot-scale process with capacities ranging from 1 to $3 \mathrm{~kg} \mathrm{~h}^{-1}$ (Park et al. 2004; Tewfik et al. 2011; Yang et al. 2011). Various studies on rice straw pyrolysis show promising results. In the investigation of Nam et al. (2015) using bench scale auger, batch, and fluidized bed reactors, a $43 \%$ bio-oil yield from rice straw was obtained using a fluidized bed reactor and $48 \%$ bio-char yield was obtained using a batch reactor. The bio-oil and bio-char heating value from the study were 31 and $19 \mathrm{MJ} \mathrm{kg}^{-1}$, respectively, and the energy conversion efficiencies of the different reactors tested ranged from 50 to 64\%. In another study (Park et al. 2014) using slow pyrolysis process, the combined energy yields from bio-oil and syngas reached $60 \%$ at pyrolysis temperatures over $500{ }^{\circ} \mathrm{C}$. Biochar served as the main product capturing $40 \%$ energy and $45 \%$ of rice straw carbon. Rice straw was also compared with other lignocellulosic biomass (i.e., corn cob, wheat straw, rice husks) in a study conducted by Biswas et al. (2017). Maximum bio-oil production from rice straw of about $28.4 \%$ was observed at $400{ }^{\circ} \mathrm{C}$.

Similar to other lignocellulosic biomass, rice straw, which contains about $38.3 \%$ cellulose, $22.2 \%$ hemicellulose, and $14.23 \%$ by weight lignin (Ukaew et al. 2018) exhibits maximum decomposition at temperatures ranging from $300-450{ }^{\circ} \mathrm{C}$ (Biswas et al. 2017). Bio-oil produced using an entrained flow type pyrolyzer at $550{ }^{\circ} \mathrm{C}$ contains high carbon content $(54.12 \% \mathrm{wt})$ and $\mathrm{H} / \mathrm{C}$ molecular ratio contributing to high energy content of about $29 \mathrm{MJ} \mathrm{kg}^{-1}$ (Tewfik et al. 2011). Rice straw bio-oil, however, was found to be slightly acidic (Yang et al. 2011; Park et al. 2004). This can be improved by pretreating the biomass by torrefaction prior to pyrolysis (Ukaew et al. 2018). The removal of minerals via dilute acid washing can also increase bio-oil production, particularly levoglucosan. Baloch et al. (2016) also suggested that leaching rice straw with water can improve the pyrolysis process. Higher bio-oil yields at temperatures greater than $500{ }^{\circ} \mathrm{C}$ were also obtained from acidwashed rice straw compared to untreated rice straw using a fixed bed reactor operated at 300 to $700{ }^{\circ} \mathrm{C}$ ( $\mathrm{Li}$ et al. 2012). Some drawbacks on rice straw pyrolysis include the need for biomass drying and grinding, which requires additional energy input to the process.

\subsubsection{Gasification}

Gasification is the thermal conversion of carbonaceous biomass in an oxygendeficient environment to produce synthesis gas (or syngas) through a series of chemical reactions. The basic reactions involved in gasification are the following (Agarwal 2014; Young 2010): 


$\begin{array}{lll}\text { Partial oxidation: } & \mathrm{C}+1 / 2 \mathrm{O}_{2} \leftrightarrow \mathrm{CO} & \Delta \mathrm{H}=-268 \mathrm{MJ} \mathrm{kmol}^{-1} \\ \begin{array}{l}\text { Complete } \\ \text { oxidation: }\end{array} & \mathrm{C}+\mathrm{O}_{2} \leftrightarrow \mathrm{CO} & \Delta \mathrm{H}=-406 \mathrm{MJ} \mathrm{kmol}^{-1} \\ \begin{array}{l}\text { Water gas reaction: } \\ \begin{array}{l}\text { Water gas shift } \\ \text { reaction: }\end{array}\end{array} & \mathrm{C}+\mathrm{H}_{2} \mathrm{O} \leftrightarrow \mathrm{CO}+\mathrm{H}_{2} & \Delta \mathrm{H}=+118 \mathrm{MJ} \mathrm{kmol}^{-1} \\ \begin{array}{l}\text { Steam methane } \\ \text { reforming: }\end{array} & \mathrm{CO}+\mathrm{H}_{2} \mathrm{O} \leftrightarrow \mathrm{CO}_{2}+\mathrm{H}_{2} & \Delta \mathrm{H}=-42 \mathrm{MJ} \mathrm{kmol}^{-1} \\ \begin{array}{l}\text { Hydrocarbon } \\ \text { reactions: }\end{array} & \mathrm{CH}_{4}+\mathrm{H}_{2} \mathrm{O} \leftrightarrow \mathrm{CO}+3 \mathrm{H}_{2} & \Delta \mathrm{H}=+88 \mathrm{MJ} \mathrm{kmol}^{-1} \\ & \mathrm{C}_{\mathrm{n}} \mathrm{H}_{\mathrm{m}}+\mathrm{nH}_{2} \mathrm{O} \leftrightarrow \mathrm{nCO} & \text { (Endothermic) } \\ & +(\mathrm{n}+\mathrm{m} / 2) \mathrm{H}_{2} & \end{array}$

Syngas is mainly composed of combustible gases, such as $\mathrm{CO}$ and $\mathrm{H}_{2}$, and its composition varies with process conditions (i.e., temperature, pressure), reactor design, feedstock characteristics, and gasifying agent (air, steam, oxygen) (Agarwal 2014). Syngas treatment processes aim to further increase combustible components (i.e., $\mathrm{H}_{2}, \mathrm{CO}, \mathrm{C}_{\mathrm{x}} \mathrm{H}_{\mathrm{y}}$ ) by removing noncombustible gases and water. Syngas can be used as an energy source for heating, drying, cooking, biofuel production, or as a cogeneration system to produce electricity. It can also be used as a feedstock for the manufacture of high-value chemical compounds. According to Young (2010), the $\mathrm{CO}$ and $\mathrm{H}_{2}$ in syngas serve as building blocks for the synthesis of various industrial chemical compounds including methanol, hydrogen, and ammonia among others. Fuels in the form of alcohols and diesel can also be produced from syngas via the Fisher-Tropsch method. The inorganic materials present in the biomass are converted into a solid rock-like material referred to as slag or vitrified slag or ash during gasification.

The technologies for gasification mostly evolved from the gasification of coal since it was one of the first technologies for syngas production. Generally, there are three basic types of reactors used for gasification: (1) moving-bed or fixed-bed gasifier, (2) fluidized-bed gasifier, and (3) entrained-flow gasifier. Table 4.6 summarizes the variation among these three gasification configurations.

Studies on rice straw gasification show initial positive results for bioenergy production. Gasification studies using rice straw in fluidized bed gasifier (to produce syngas) resulted in $61 \%$ hot gas efficiency and $52 \%$ cold gas efficiency, with the higher heating value of about 5.1 $\mathrm{MJ} \mathrm{N} \mathrm{m}^{-3}$ (Calvo et al. 2012). Bed agglomeration was solved by substituting the usual alumina-silicate bed by a mixture of aluminasilicate sand and magnesium oxide (MgO) (Calvo et al. 2012). Another study on gasification showed that the presence of potassium carbonate $\left(\mathrm{K}_{2} \mathrm{CO}_{3}\right)$ improved the production of $\mathrm{H}_{2}$-rich gas with yields up to $59.8 \% \mathrm{H}_{2}$ (Baloch et al. 2016).

The single largest problem in gasification is the occurrence of tar in the producer gas, which requires strategies for dealing with the tar either by removal using filters, scrubbers, or condensers, or by in situ conversion through catalytic cracking or reforming of tar, both of which are still under development (Brandin et al. 2011). 
Table 4.6 Process description and application of various gasification types

\begin{tabular}{|c|c|c|c|c|c|}
\hline Type & $\begin{array}{l}\text { Process } \\
\text { description }\end{array}$ & Other characteristics & $\begin{array}{l}\text { Outlet } \\
\text { gas } \\
\text { temp. } \\
\left({ }^{\circ} \mathrm{C}\right)\end{array}$ & $\begin{array}{l}\text { Technology } \\
\text { providers }\end{array}$ & Application \\
\hline $\begin{array}{l}\text { Fixed or } \\
\text { moving } \\
\text { bed }\end{array}$ & $\begin{array}{l}\text { Feedstock enters } \\
\text { at the top while } \\
\text { steam/air enters at } \\
\text { the bottom; } \\
\text { syngas exits from } \\
\text { the top; slag or } \\
\text { ash is removed } \\
\text { from the bottom; } \\
\text { may be operated } \\
\text { below or above } \\
\text { ash-slagging } \\
\text { temperature range }\end{array}$ & $\begin{array}{l}\text { Low oxygen } \\
\text { requirement; tars and } \\
\text { oils are produced; } \\
\text { limited ability to } \\
\text { handle fine feed; } \\
\text { slagging and } \\
\text { nonslagging ash } \\
\text { depending on } \\
\text { operating temperature }\end{array}$ & $\begin{array}{l}430- \\
650\end{array}$ & $\begin{array}{l}\text { British gas/Lurgi } \\
\text { (BGL) and } \\
\text { Lurgi }\end{array}$ & $\begin{array}{l}42 \% \text { of total } \\
\text { installed } \\
\text { gasification } \\
\text { capacity } \\
\text { worldwide }\end{array}$ \\
\hline $\begin{array}{l}\text { Flui-dized } \\
\text { bed }\end{array}$ & $\begin{array}{l}\text { Feedstock enters } \\
\text { the side of the } \\
\text { reactor while } \\
\text { steam/air enters at } \\
\text { the bottom; } \\
\text { syngas exits from } \\
\text { the top; ash is } \\
\text { removed from the } \\
\text { bottom; steam/air } \\
\text { fluidize the feed } \\
\text { particles; } \\
\text { temperature is } \\
\text { maintained below } \\
\text { the ash fusion } \\
\text { range }\end{array}$ & $\begin{array}{l}\text { Moderate oxygen/ } \\
\text { steam requirement; } \\
\text { nonslagging ash; can } \\
\text { process a wide range } \\
\text { of feedstock; bed } \\
\text { temperature is uniform } \\
\text { and moderate; } \\
\text { extensive char } \\
\text { recycling }\end{array}$ & $\begin{array}{l}930- \\
1040\end{array}$ & $\begin{array}{l}\text { HTW, KRW, } \\
\text { KBR and } \\
\text { Winkler }\end{array}$ & $\begin{array}{l}2 \% \text { of total } \\
\text { installed } \\
\text { gasification } \\
\text { capacity } \\
\text { worldwide }\end{array}$ \\
\hline $\begin{array}{l}\text { En-trained } \\
\text { flow }\end{array}$ & $\begin{array}{l}\text { Feedstock and } \\
\text { steam/air enters at } \\
\text { the top; syngas } \\
\text { exits near the } \\
\text { bottom; ash is } \\
\text { removed from the } \\
\text { bottom; operates } \\
\text { at temperatures } \\
\text { above ash- } \\
\text { slagging } \\
\text { conditions }\end{array}$ & $\begin{array}{l}\text { Reliable and proven } \\
\text { design; no internal } \\
\text { moving parts; compact } \\
\text { size; minimal } \\
\text { byproducts; has ability } \\
\text { to supply syngas at } \\
\text { high pressures; } \\
\text { uniform temperature; } \\
\text { short residence time; } \\
\text { slagging ash; feed } \\
\text { should be finely } \\
\text { divided and } \\
\text { homogenous; large } \\
\text { oxygen requirement; } \\
\text { high temperature } \\
\text { slagging operation; } \\
\text { possible entrainment } \\
\text { of molten slag in the } \\
\text { raw syngas }\end{array}$ & $\begin{array}{l}1230- \\
1650\end{array}$ & $\begin{array}{l}\text { ConocoPhillips, } \\
\text { future energy, } \\
\text { GE Energy, and } \\
\text { Shell }\end{array}$ & $\begin{array}{l}56 \% \text { of total } \\
\text { installed } \\
\text { gasification } \\
\text { capacity } \\
\text { worldwide }\end{array}$ \\
\hline
\end{tabular}

Source: Adapted from Young (2010) 


\subsubsection{Combustion}

Combustion is the confined and controlled process of burning organic materials (i.e., biomass, wastes) with sufficient amount of air (usually 110 to $150 \%$ of stoichiometric oxygen) at temperatures typically between 700 and $1350{ }^{\circ} \mathrm{C}$ to produce heat, mechanical, or electrical energy using various equipment such as stoves, furnaces, boilers, etc. (Tan 2013). Any kind of waste material with moisture content of $<50 \%$ can be used as fuel for combustion (Agarwal 2014). This process can reduce the volume of waste up to about $90 \%$ ( $70 \%$ by mass) depending on the feedstock and reactor types, and process conditions. However, efficient air pollution control devices are required for treatment of the flue gases, which may contain various air pollutants (i.e. NOx, SOx, PMs, dioxins). Bottom ash and fly ash are also produced from the inorganic fraction of the fuel used. The scale of a combustion plant may range from domestic-level heating to large industrial plant. The complete combustion reaction of hydrocarbons is shown below:

$$
\mathrm{C}_{\mathrm{n}} \mathrm{H}_{\mathrm{m}}+(n+m / 4) \mathrm{O}_{2} \rightarrow n C \mathrm{O}_{2}+(m / 2) \mathrm{H}_{2} \mathrm{O}
$$

Unlike for rice husks, research and applications of bioenergy via thermal conversion of rice straw are in developmental stage. And among the different thermochemical processes, direct combustion is the most established because of its simplicity and high efficiency; thus, it can be used for the economic heat generation from biomass (Nussbaumer 2003). A study conducted at IRRI in 2018 used a bench scale, direct combustion rice straw furnace (Fig. 4.2a) to heat air for paddy drying using a flatbed dryer. Results from the study show that at feed rates of 20 to $30 \mathrm{~kg} \mathrm{~h}^{-1}$ rice straw, the energy output of the furnace ranged from 200 to $350 \mathrm{MJ} \mathrm{h}^{-1}$; and the drying air temperature is raised from 14 to more than $30{ }^{\circ} \mathrm{C}$ above ambient, proving to be sufficient for paddy drying applications (Migo 2019). In addition, drying air efficiency ranged from 60 to over $85 \%$ in the bench scale application (Migo 2019). However, due to the ash accumulation problem, manual feeding was necessary to break the ash (Fig. 4.2b).
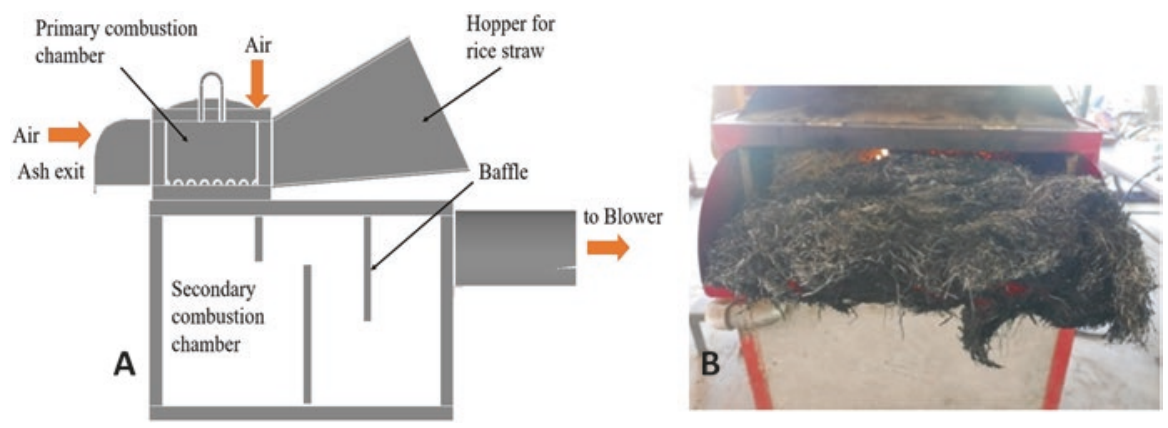

Fig. 4.2 (a) Diagram of rice straw furnace and (b) photo of refuse ash 
There are many ash-related issues encountered in combusting rice straw and other herbaceous biomass including: accumulation, slagging, fouling, and corrosion of the boiler due to the chlorine and alkali content (Zafar 2018). Although there are no reported large-scale direct combustion power plants using rice straw as of 2018, large-scale application could be highly feasible — as demonstrated by combined heat and power plants (CHPs) in Europe that operate using wheat and oat straw. Traditionally, European power plants feed straw bales directly in combustion chambers (also known as "Vølund cigar feeding"), to save on additional energy input for dissolving the bales; however, more advanced power plants use shredded straw, combining it with coal (i.e., coal and straw co-firing) in fluidized bed systems (Zafar 2018) for higher efficiencies. Thus, rice straw pretreatment may be necessary before energy conversion but may have a negative effect in the overall energy balance.

In terms of pretreatment, particle size may be reduced after 2 weeks of air drying. Chou et al. (2009) reported that rice straw should be reduced to about 2-5 mm length for energy conversion. Rice straw may also be compressed into cubes with sides of $50 \mathrm{~mm}^{3}$ using hot press machines to increase its density and energy content for a more uniform combustion (Kargbo et al. 2010). In order to solve slagging and fouling problems, leaching may be used as a pretreatment method. In a study by Kargbo et al. (2010), pretreatment was done by spraying water on spread rice straw (not more than $30 \mathrm{~cm}$ thick) over a steel mesh, which resulted in reduced concentration of $\mathrm{K}, \mathrm{Na}$, and $\mathrm{Cl}$.

The size of currently available biomass combustion systems ranges from a few $\mathrm{kW}$ up to more than $100 \mathrm{MW}$ (Nussbaumer 2003). Biomass combustion systems can be classified according to capacity: small-scale (less than $100 \mathrm{kWth}$ ), mediumscale (from $100 \mathrm{kWth}$ to $10 \mathrm{MWth}$ ), and large-scale (greater than $10 \mathrm{MWth}$ ) (Obernberger 2008). However, because of logistical problems in gathering rice straw and transporting it to power plants, small-scale rice straw bioenergy applications near farming fields are more common.

\subsection{Nonenergy Thermal Conversion Byproducts}

This section focuses on the nonenergy applications of thermal conversion products, such as biochar from pyrolysis and ash residues from gasification and combustion systems.

\subsubsection{Biochar}

Biochar is the charcoal-like carbon-rich residue produced during biomass pyrolysis. Generally, it must contain at least $50 \%$ wt carbon, $75 \%$ of which is fixed carbon (Jonsson 2016). Due to the release of volatile matter from the biomass during pyrolysis, biochar contains relatively high carbon and lower oxygen content than the raw 


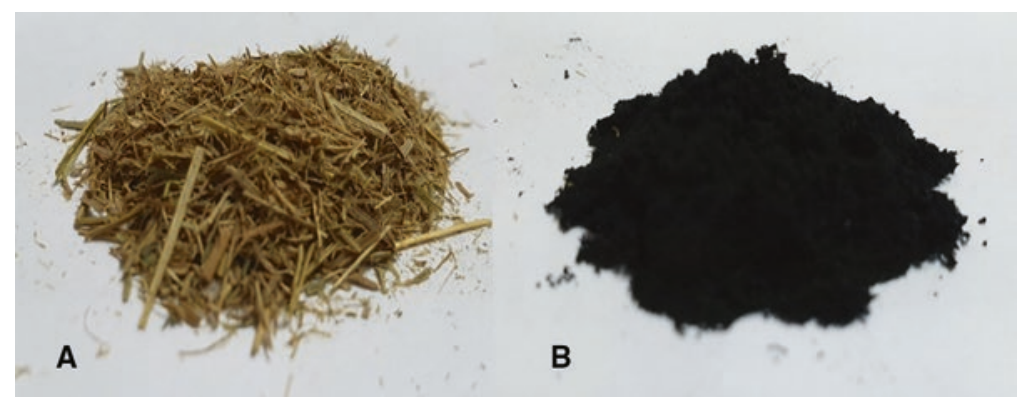

Fig. 4.3 (a) Rice straw and (b) rice straw-derived biochar

biomass, which is desirable especially if a high heating value is needed. The low amount of sulfur and nitrogen in biochar is also favorable in preventing high emissions of sulfur and nitrogen oxides into the atmosphere (Liu and Han 2015) (Fig. 4.3).

Biochar is used in agriculture to condition the soil, increase crop production, and mitigate GHG emissions. It can serve as a water reservoir due to its high waterretention capacity (Schimdt 2012). Also, it can bind nutrients into its structure, thus, slowing the rate of nutrient loss (Amarasinghe et al. 2016). Biochar has generally a neutral to alkaline $\mathrm{pH}$, hence, it can also be applied to adjust the $\mathrm{pH}$ value of acidic soils (Zhang et al. 2015; Ahmad et al. 2014). In a study conducted by Wu et al. (2012), rice straw was used as a feedstock for slow pyrolysis to determine the yields and characteristics of biochar produced at various temperatures and residence times. Based on their study, rice straw biochar has high surface alkalinity, high cation exchange capacity, and contains high amounts of macronutrients (i.e., phosphorus, potassium) indicating its suitability as soil enhancer. The biochar produced at higher pyrolysis temperatures is more carbon-enriched and contains aromatic compounds, which may be recalcitrant in soil improving its capability for carbon sequestration (Thammasom et al. 2016; Wu et al. 2012).

Increased carbon storage in soil with biochar was also reported by Yun-Feng et al. (2014), which may be due to higher aryl- and carbonyl-C contents of rice straw biochar. Yang et al. (2019) studied the effect of applying rice straw biochar in paddy fields under controlled irrigation. Their results indicate that biochar loading at 20 and $40 \mathrm{tha}^{-1}$ can reduce $\mathrm{CH}_{2}$ and $\mathrm{N}_{2} \mathrm{O}$ emissions, increase rice yields, and improve irrigation water productivity under controlled irrigation. Qin et al. (2016) reported the same results for $20-\mathrm{t}-\mathrm{ha}^{-1}$ biochar loading in rice fields, which resulted to maximum GHG-emission reduction of about $36.24 \%$ compared to a traditional field management method involving chemical fertilizer application. The reduction in GHG emissions was attributed to the increase in biodiversity and abundance of methanotrophic microbes, increased soil $\mathrm{pH}$, increased soil aeration, and the recalcitrance of biochar.

Biochar can also be used in treating various organic and inorganic contaminants, such as heavy metals, herbicides, and antibiotics in soil and aqueous solutions (Tan 
et al. 2015. It is comparable to activated carbon, which is the most widely used adsorbent. But unlike activated carbon, biochar produced at certain pyrolysis conditions can be used directly without activation due to partitioning in the noncarbonized fractions or electrostatic attraction with O-containing carboxyl, hydroxyl, and phenolic surface functional groups which could effectively bind with contaminants (Uchimiya et al. 2012).

Generally, the functionality of biochar as a sorbent varies with pyrolysis temperature since the release of $\mathrm{O}$ - and $\mathrm{H}$-containing functional groups changes its surface polarity and aromaticity. Different types of contaminants also have varying affinities with biochar. Organic contaminants can be removed from the soil and aqueous solutions through adsorption, partitioning in the noncarbonized fraction, or electrostatic attraction while inorganic pollutants can be removed by physical adsorption, ion exchange, electrostatic attraction, or precipitation (Ahmad et al. 2014). Rice straw-derived biochar has also been found to be effective in treating various soil and aqueous pollutants including pentachlorophenol, dyes, and lead (Lou et al. 2011; Qiu et al. 2009; Jiang et al. 2012).

\subsubsection{Slag, Vitrified Slag or Ash}

Solid rock-like material, referred to as slag or vitrified slag, and greyish residue called ash are considered to be byproducts of the gasification and combustion processes. These materials are derived from the inorganic fraction of the biomass. Process conditions, such as temperature under which the inorganic materials from the feedstock are being converted, determine the property of this material as to whether a slag, vitrified slag, or ash will be formed. Heavy metals including chromium, lead, and mercury, which are considered as environmental hazards, may be present in the slag, vitrified slag, or ash. Hence, the leachability of these metals from the material should be tested. Slag, vitrified slag, and ash are typically disposed of in landfills but these can potentially be converted into high-value products. Due to its rock-like characteristics, slag or vitrified slag may be used as construction material, aggregates in asphalt or cement-concrete, pipe bedding material, decorative tiles, and others if the Toxicity Characteristic Leaching Procedure (TCLP) standards are being met. Ash, on the other hand, may be used as an additive for cement manufacturing (Young 2010).

Ash from gasification or combustion operations may also be utilized for cement and concrete production, road pavement, glasses and ceramics, fertilizers, stabilizing agent, , and zeolite production (Lam et al. 2010). Furthermore, rice straw ash has a high $\mathrm{SiO}_{2}$ content ranging from 67.68 to $82.6 \%$ by weight as discussed in Chap. 1 . High silica content of about $73.65 \% \mathrm{SiO}_{2}$ of rice straw ash was also reported by Chen et al. (2017). Silica from ash can be used to treat effluents containing heavy metals (i.e. $\mathrm{Pb}^{2+}, \mathrm{Cu}^{2+}, \mathrm{Cd}^{2+}$, and $\mathrm{Cr}^{2+}$ ). Silica extraction from combustion ash has already been studied by Caraos (2018) and Liu et al. (2014) via alkaline fusion and hydrothermal desilication methods. 


\subsection{Comparison of Thermal Conversion Technologies}

Comparisons of thermal conversion methods will be discussed in this section based on energy conversion, technological maturity, and potential environmental issues that may arise from their operation.

\subsubsection{Energy Conversion}

The energy conversion efficiency, or thermal efficiency, is the ratio of the energy generated from the fuel using the selected thermal conversion process and the net calorific value of the fuel. The energy conversion efficiencies of thermal processes are summarized in Table 4.7. On average, about a 60\% energy conversion efficiency can be achieved using rice straw as a biomass feedstock. In the study conducted by Nam et al. (2015), energy recovery was accounted for the energy contained in the three pyrolysis products. Higher energy recovery was recorded for char in the bench-scale auger-type and fixed-bed pyrolyzer, while in the fluidized-bed reactor bio-oil was the main energy product. Park et al. (2014) also reported that char contained most of the biomass energy recovered under slow pyrolysis. The energy efficiency for gasification, on the other hand, ranged from 52 to $61 \%$, which is still comparable with other thermal technologies. Lower energy yield was reported by Darmawan et al. (2017); however, this result was obtained using a simulated process only.

Table 4.7 A comparison of thermochemical conversion technologies using rice straw

\begin{tabular}{|c|c|c|c|c|c|}
\hline $\begin{array}{l}\text { Thermal conversion } \\
\text { process }\end{array}$ & Scale & $\begin{array}{l}\text { Rice straw } \\
\text { feed rate }\end{array}$ & $\begin{array}{l}\text { Energy } \\
\text { conversion } \\
\text { efficiency, \% }\end{array}$ & $\begin{array}{l}\text { Reactor } \\
\text { temperature, } \\
{ }^{\circ} \mathrm{C}\end{array}$ & Sources \\
\hline Direct combustion & $\begin{array}{l}\text { Bench } \\
\text { scale }\end{array}$ & $\begin{array}{l}20- \\
30 \mathrm{~kg} \mathrm{~h}^{-1}\end{array}$ & $60-85$ & $300-500$ & Migo (2019) \\
\hline $\begin{array}{l}\text { Pyrolysis (using } \\
\text { batch and fluidized } \\
\text { bed reactors) }\end{array}$ & $\begin{array}{l}\text { Bench } \\
\text { scale }\end{array}$ & N/A & $64.6-75$ & 500 & $\begin{array}{l}\text { Nam et al. } \\
(2015)\end{array}$ \\
\hline Slow pyrolysis & Lab scale & N/A & $80-90$ & $>400$ & $\begin{array}{l}\text { Park et al. } \\
(2014)\end{array}$ \\
\hline $\begin{array}{l}\text { Gasification (using } \\
\text { fluidized bad reactor) }\end{array}$ & $\begin{array}{l}\text { Bench } \\
\text { scale }\end{array}$ & $3.6-5.4$ & $52-61$ & $700-850$ & $\begin{array}{l}\text { Calvo et al. } \\
(2012)\end{array}$ \\
\hline $\begin{array}{l}\text { Gasification (using } \\
\text { entrained flow and } \\
\text { torrefied biomass) }\end{array}$ & $\begin{array}{l}\text { Simulated } \\
\text { process }\end{array}$ & $12.4 \mathrm{t} / \mathrm{h}$ & 43 & 1200 & $\begin{array}{l}\text { Darmawan } \\
\text { et al. (2017) }\end{array}$ \\
\hline $\begin{array}{l}\text { Gasification (in the } \\
\text { presence of } \mathrm{K}_{2} \mathrm{CO}_{3} \text { ) }\end{array}$ & Lab scale & N/A & & 750 & $\begin{array}{l}\text { Baloch et al. } \\
\text { (2016) }\end{array}$ \\
\hline
\end{tabular}




\subsubsection{Technology and Commercial Maturity}

Direct combustion technology is by far the most technologically developed and commercially available thermal process for biomass. According to Tan (2013), commercial availability represents the market availability of the technology at a commercial scale capacity (at least $25 \mathrm{MW}$ or $300 \mathrm{t} \mathrm{day}^{-1}$ ). Although there have been a few studies written on large-scale combustion of rice straw for power generation, Boucher et al. (2013) reported that there are at least three power plants producing 24-25 MW in China, which are known to use rice straw as part of the biomass fuel and around 15 biomass power projects in operation by the end of 2012. Some power plants using rice straw as feedstock were also installed in India and Thailand; however, problems on straw collection and feeding especially at large-scale operations led to their closure. This experience suggests that small combustion systems similar to the farm-scale paddy flatbed dryer developed at IRRI, which can be placed near rice fields, may be more feasible (Boucher et al. 2013; Migo 2019). Direct combustion is also highly favored by industrialized countries compared to other conversion technologies due to its lower annual capital cost, operational cost, and higher daily throughput.

Gasification, on the other hand, is relatively more advanced in terms of technological status as compared to pyrolysis. While no commercial rice straw gasification plants have been installed, other biomass materials, such as wood chips or rice husks, have been used for more than 100 years. Fluidized bed systems are in its demonstration phase while downdraft and updraft gasifiers are already in their early commercial stages (IFC 2017). Ouda et al. (2016) also reported that Asia has advanced greatly in the gasification technology over the past few years and can be considered as one of the most favorable markets for gasification technology followed by Europe, Africa, and USA.

Brandin et al. (2011), for example, assessed five gasification plants using different biomass materials as fuel in Europe with electrical power outputs in the range of from $17.5 \mathrm{kWe}$ to $6 \mathrm{MWe}$ and concluded that the technology is generally sufficiently mature for commercialization, although some unit operations, for example catalytic tar reforming, still need further development. All plants have a fully automatic operation and are equipped with complex tar removal systems. Since these are all pilot plants, data about commercial feasibility were not yet available. Further development is also needed to increase the biofuel-to-electricity efficiency, currently at from $20-25 \%$, to $30-40 \%$ and overall performance efficiency to around $90 \%$.

Dimpl (2010) analyzed experiences with small-scale applications of the gasification technology worldwide over the last three decades. The study concluded that there is not yet any standard gasifier technology complying with environmental standards appropriate for rural small-scale applications readily available off the shelf. In general, the small-scale power-gasifier technology proved to be unreliable and expensive and to minimize cost systems for capturing carcinogenic waste are often not installed or not very effective. 


\subsubsection{Environmental and Health Impacts}

Among the thermal conversion technologies, pyrolysis results in the least emissions since all products can be used as energy sources or marketable nonenergy products. Studies also show that carbon can be sequestered in the soil by using char as a soil enhancer or fertilizer thus reducing GHG emissions (Roos 2009; Ahmad et al. 2014). Moreover, the use of char as fertilizer can reduce the need for chemical fertilizers and increase nutrient uptake efficiency. However, these positive impacts may be offset if the energy input to the process will come from fossil fuels. This provides motivation for the recirculation of heat from syngas combustion as suggested by Agarwal (2014). Upgrading of the bio-oil, on the other hand, may render it as a comparable replacement to petroleum-derived liquid transport fuels.

Compared to combustion, gasification has lower carbon and NOx emissions since NOx are produced at temperatures higher than the gasification range. Combustion only produces heat, while gasification produces excess heat and gaseous fuel, which can be used in a reciprocating engine, gas turbine, fuel cells or in an integrated gasification combined cycle resulting to higher energy efficiency and lower GHG emissions (Roos 2009). Also, direct combustion may result in emission of toxic substances such as dioxins and furans especially if chlorinated compounds are present in the feedstock. Untreated rice straw has about $0.4 \% \mathrm{Cl}$ (Roos 2009). Pyrolysis, on the other hand, has the advantage of producing gaseous product that is free from such pollutants due to its inert atmosphere (Agarwal 2014).

More attention is needed by the research community to find solutions to potential health hazards from small-scale gasification. To minimize investment costs to make gasification economically viable, often simple filters are installed for tar removal in small gasification plants, which often produce much carcinogenic waste, especially in the case of wet stripping of the gas. This causes severe environmental and health threats (Dimpl 2010). None of the small-scale plants that were repeatedly monitored in studies since 1995 (Stassen 1995; Dimpl 2010, IRRI unpubl. Trip reports from Myanmar and Cambodia, 2008-13) took adequate measures to deal with the condensates; instead the pollutants were freely discharged into the environment. In addition, the operators dealing with these contaminated condensates often did not use protective clothing or gloves and some complained about frequent headaches.

Shackley et al. (2011) studied soil improvement and carbon sequestration using gasification biochar from rice husk gasifiers installed in Cambodian rice mills and ice factories and highlight that questions remain regarding the safety of the biochar for human health. 


\subsection{Conclusions and Recommendations}

This chapter shows the potential of rice straw in producing bioenergy in the form of biofuels, heat, steam, or power using thermal conversion technologies. Pyrolysis, gasification, and combustion are at different stages of development. Combustion systems for biomass are commercially available while gasification and pyrolysis are still in the demonstration and research stages, respectively. These processes show potential for large-scale application; however, problems associated with rice straw collection, storage, and transportation makes small- or field-scale application a more viable alternative. Further research and development is needed on gasification in the areas of gas cleaning/upgrading, utilization of produced heat to increase overall efficiency and system integration/optimization.

Compared to pyrolysis or gasification, combustion systems are more technologically mature but proper air pollution control devices should be part of these installations to curtail release of harmful gases. Pyrolysis, on the other hand, has lesser emissions due to its inert environment and the residual product—biochar-can be used for carbon sequestration. However, more studies are needed for the feasibility of pyrolysis of rice straw on a commercial scale. In general, the thermal conversion technologies can recover energy from rice straw up to about $60 \%$ and the marketable non-energy by-products can potentially improve process economics.

\section{References}

Abrego J, Sanchez JL, Arauzo J, Fonts I, Gil-Lalaguna N, Atienza-Martinez M (2013) Technical and energetic assessment of a three-stage thermochemical treatment for sewage sludge. Energy Fuel 27:1026-1034

Agarwal M (2014) An investigation on the pyrolysis of municipal solid waste. Unpublished thesis. RMIT

Ahmad M, Rajapaksha AU, Lim JE, Zhang M, Bolan N, Mohan D, Vithanage M, Lee SS, Ok YS (2014) Biochar as a sorbent for contaminant management in soil and water: a review. Chemosphere 99:19-33

Amarasinghe HAHI, Gunathilake SK, Karunarathna AK (2016) Ascertaining of optimum pyrolysis conditions in producing refuse tea biochar as a soil amendment. Procedia Food Sci 6:97-102

Amen-Chen C, Pakdel H, Roy C (1997) Separation of phenols from eucalyptus wood tar. Biomass Bioenergy 13:25-37

Baloch HA, Yang T, Sun H, Li J, Nizamuddin S, Li R et al (2016) Parametric study of pyrolysis and steam gasification of rice straw in presence of $\mathrm{K}_{2} \mathrm{CO}_{3}$. Korean J Chem Eng 33(9):2567-2574. https://doi.org/10.1007/s11814-016-0121-7

Biswas B, Pandey N, Bisht Y, Singh R, Kumar J, Bhaskar T (2017) Pyrolysis of agricultural biomass residues: comparative study of corn cob, wheat straw, rice straw, and rice husk. Bioresour Technol 237:57-63

Boucher E, Guillemot A, Pasquiou V (2013) Feasibility study for the implementation of two ORC power plants of $1 \mathrm{MWe}$ each using rice straw as fuel in the context of a public-private partnership with the institutions PhilRice and UPLB. Enertime, Puteaux

Brandin J, Tunér M, Odenbrand I (2011) Small-scale gasification: gas engine CHP for biofuels. Swedish Energy Agency report, Växjö/Lund. Linnaeus University and Lund University 
Bridgwater T (2006) Review: biomass for energy. J Sci Food Agr 86:1755-1768

Bridgwater A (2012) Review of fast pyrolysis of biomass and product upgrading. Biomass Bioenergy 38:68-94. https://doi.org/10.1016/j.biombioe.2011.01.048

Calvo L, Gil M, Otero M, Morán A, García A (2012) Gasification of rice straw in a fluidizedbed gasifier for syngas application in close-coupled boiler-gasifier systems. Bioresour Technol 109:206-214. https://doi.org/10.1016/j.biortech.2012.01.027

Cao J-P, Zhao X-Y, Morishita K, Wei X-Y, Takarada T (2010) Fractionation and identification of organic nitrogen species from bio-oil produced by fast pyrolysis of sewage sludge. Bioresour Technol 101:7648-7652

Capareda SC (2014) Introduction to biomass energy conversions. CRC, Boca Raton

Caraos NAP (2018) Parametric analysis of silica extraction process via alkaline fusion and hydrothermal desilication methods from municipal solid waste bottom ash derived from direct combustion. Unpubl. University of the Philippines Los Baños

Chen D, Yin L, Wang H, He P (2015) Pyrolysis technologies for municipal solid waste: a review. Waste Manag 37:116-136

Chen T, Cao J, Jin B (2017) The effect of rice straw gasification temperature on the release and occurrence modes of Na and K in a fluidized bed. Appl Sci 7(12):1207

Chou C, Lin S, Lu W (2009) Preparation and characterization of solid biomass fuel made from rice straw and rice bran. Fuel Process Technol 90(7-8):980-987. https://doi.org/10.1016/j. fuproc.2009.04.012

Czernik S (2010) Fundamentals of charcoal production. National Renewable Energy Laboratory (NREL), Newcastle

Darmawan A, Fitrianto AC, Aziz M, Tokimatsu K (2017) Enhanced electricity production from rice straw. Energy Procedia 142:271-277

Demirbas MF (2001) Biomass resource facilities and biomass conversion processing for fuels and chemicals. Energy Convers Manag 42:1357-1378

Demirbas A (2004) Effect of temperature and particle size on biochar yield from pyrolysis of agricultural residues. J Anal Appl Pyrolysis 721:243-248

Demirbas MF, Balat M, Balat H (2009) Potential contribution of biomass to the sustainable energy development. Energy Convers Manag 50:1746-1760

Dimpl E (2010) Small-scale electricity generation from biomass. Part I: biomass gasification, 1st edn. GTZ-HERA. Poverty-oriented Basic Energy Service

Dong J, Chi Y, Tang Y, Ni M, Nzihou A, Weiss-Hortala E, Huang Q (2016) Effect of operating parameters and moisture content on municipal solid waste pyrolysis and gasification. Energy Fuel 30(5):3994-4001

Duku MH, Gu S, Hagan EB (2011) Biochar production potential in Ghana: a review. Renew Sustain Energy Rev 15:3539-3551

Fu P, Hu S, Xiang J, Sun L, Su S, Wang J (2012) Evaluation of the porous structure development of chars from pyrolysis of rice straw: effects of pyrolysis temperature and heating rate. J Anal Appl Pyrolysis 98:177-183

Huang YF, Kuan WH, Chiueh PT, Lo SL (2011) Pyrolysis of biomass by thermal analysis-mass spectrometry (TA-MS). Bioresour Technol 102:3527-3534

IFC (International Finance Corporation) (2017) Converting biomass to energy: a guide for developers and investors. Retrieved 10 July 2018 https://www.ifc.org/wps/wcm/connect/7a1813bcb6e8-4139-a7fc-cee8c5c61f64/BioMass_report_06+2017.pdf?MOD=AJPERES

Isahak NRW, Hisham MWM, Yarmo MA, Hin TY (2012) A review on bio-oil production from biomass by using pyrolysis method. Renew Sust Energ Rev 16:5910-5923

Jiang T-Y, Jiang J, Xu R-K, Li Z (2012) Adsorption of $\mathrm{Pb}$ (II) on variable charge soils amended with rice-straw derived biochar. Chemosphere 89(3):249-256

Jonsson E (2016) Slow pyrolysis in Brista. Retrieved March 30, 2017 from www.diva-portal.org

Kargbo F, Xing J, Zhang Y (2010) Property analysis and pretreatment of rice straw for energy use in grain drying: a review. Agric Biol J N Am 1(3):195-200. https://doi.org/10.5251/ abjna.2010.1.3.195.200 
Kenney KL, Smith WA, Greasham GJ, Westover TL (2013) Understanding biomass feedstock variability. Biofuels 4(1):111-127

Lam CHK, Ip AWM, Barford JP, McKay G (2010) Use of incineration MSW ash: review. Sustainability 2:1943-1968. https://doi.org/10.3390/su2071943

Li S, Yu S, Wang F-C, Wang J (2012) Pyrolytic characteristics of rice straw and its constituents catalyzed by internal alkali and alkali earth metals. Fuel 96:586-594

Liu Z, Han G (2015) Production of solid fuel biochar from waste biomass by low temperature pyrolysis. Fuel 158:159-165

Liu W-J, Tian K, Jiang H, Zhang X-S, Yang G-X (2013) Preparation of liquid chemical feedstocks by co-pyrolysis of electronic waste and biomass without formation of polybrominated dibenzop-dioxins. Bioresour Technol 128:1-7

Liu Z-S, Li WK, Huang C-Y (2014) Synthesis of mesoporous silica materials from municipal solid waste incinerator bottom ash. Waste Manag 34:893-900

Lohri CR, Sweeney D, Rajabu HM (2015) Carbonizing urban biowaste for low-cost char production in developing countries: a review of knowledge, practices and technologies. Joint Report by Eawag, MIT D-Lab and UDSM. https://www.eawag.ch/fileadmin/Domain1/Abteilungen/sandec/publikationen/SWM/Carbonization_of_Urban_Bio-waste/Carbonization_of_Biowaste_ in_DCs_FINALx.pdf

Lou L, Wu B, Wang L, Luo L, Xu X, Hou J, Xun B, Hu B, Chen Y (2011) Sorption and ecotoxicity of pentachlorophenol polluted sediment amended with rice-straw derived biochar. Bioresour Technol 102(5):4036-4041

Lu R, Sheng G-P, Hu Y-Y, Zheng P, Jiang H, Tang Y, Yu H-Q (2011) Fractional characterization of a bio-oil derived from rice husk. Biomass Bioenergy 35:671-678

Maguyon MCC, Capareda SC (2013) Evaluating the effects of temperature on pressurized Ppyrolysis of Nannochloropsis oculata based on products yields, and characteristics. Energy Convers Manag J 76:764-773

Maguyon-Detras MC, Capareda SC (2017) Determining the operating condition for maximum bio-oil production from pyrolysis of Nannochloropsis oculata. Philippine J Crop Sci 42(2):37_ 47. https://www.cabdirect.org/cabdirect/abstract/20173297237

Mahinpey N, Murugan P, Mani T, Raina R (2009) Analysis of bio-oil, biogas and biochar from pressurized pyrolysis of wheat straw using a tubular reactor. Energy Fuel 23:2736-2742. https://doi.org/10.1021/ef8010959

McKendry P (2002) Energy production from biomass (part 2): conversion technologies. Bioresour Technol 83:47-54

Migo MVP (2019) Optimization and life cycle assessment of the direct combustion of rice straw using a small scale, stationary grate furnace for heat generation. Unpubl. Masters thesis. University of the Philippines Los Baños

Nam H, Capareda SC, Ashwath N, Kongkasawan J (2015) Experimental investigation of pyrolysis of rice straw using bench-scale auger, batch and fluidized bed reactors. Energy 93:2384-2394

Nussbaumer T (2003) Combustion and co-combustion of biomass: fundamental, technologies, and primary measures for emission reduction. Energy Fuel 17(6):1510-1521. https://doi. org/10.1021/ef030031q

Obernberger I (2008) Industrial combustion of solid biomass fuels: state of the art and relevant future developments. [PowerPoint slides]. Retrieved from: https://www.bios-bioenergy.at/ uploads/media/Paper-Obernberger-Industrial-combustion-of-solid-bimass-fuels-2008-10-15. pdf

Ouda O, Raza S, Nizami A, Rehan M, Al-Waked R, Korres N (2016) Waste to energy potential: a case study of Saudi Arabia. Renew Sust Energ Rev 61:328-340. https://doi.org/10.1016/j. rser.2016.04.005

Park Y-K, Jeon J-K, Kim S, Kim JS (2004) Bio-oil from rice straw by pyrolysis using fluidized bed and char removal system. Preprints Papers Am Chem Soc Div Fuel Chem 49(2):800-801

Park J, Lee Y, Ryu C, Park Y-K (2014) Slow pyrolysis of rice straw: analysis of products properties, carbon and energy yields. Bioresour Technol 155:63-70 
Pattiya A (2011) Bio-oil production via fast pyrolysis of biomass residues from cassava plants in a fluidized-bed reactor. Bioresour Technol 102:1959-1967

Pollex A, Ortwein A, Kaltschmitt M (2011) Thermo-chemical conversion of solid biofuels. Biomass Convers Biorefin 2(1):21-39. https://doi.org/10.1007/s13399-011-0025-Z

Qin X, Li Y, Wang H, Liu C, Li J, Wan Y, Gao Q, Fan F, Liao Y (2016) Long-term effect of biochar application on yield-scaled greenhouse gas emissions in a rice paddy cropping system: a fouryear case study in South China. Sci Total Environ 569-570:1390-1401

Qiu Y, Zheng Z, Zhou Z, Sheng GD (2009) Effectiveness and mechanisms of dye adsorption on a straw-based biochar. Bioresour Technol 100(21):5348-5351

Roos CJ (2009) Clean heat and power using biomass gasification for industrial and agricultural projects. Northwest CHP Application Center, Olympia

Schimdt HP (2012) 55 uses of biochar. J Terrior-Wine Biodivers (2008). Retrieved September 27, 2016 from http://www.ithaka-journal.net/55-anwendungen-von-pflanzenkohle?lang=en

Shackley S, Carter S, Knowles T, Middelink E, Haefele S, Haszeldine S (2011) Sustainable gasification-biochar systems? A case-study of rice-husk gasification in Cambodia, Part II: field trial results, carbon abatement, economic assessment and conclusions. Energy Policy 41:618-621 https://www.geos.ed.ac.uk/research/subsurface/diagenesis/ Sustainable_gasification_biochar_systems._A_case_study_of_rice_husk_gasification_in_ Cambodia_gasification_Part_II_Field_trial_results,_carbon_abatement,_economic_assessment_and_conclusions_Energy_Policy_Shackley_Carter_Haszeldine_2012.pdf

Srinivasan V, Adhikari S, Chattanathan SA, Park S (2012) Catalytic pyrolysis of torrefied biomass for hydrocarbons production. Energy Fuel 12:7347-7353. https://doi.org/10.1021/ef301469t

Stassen HE (1995) Small-scale biomass gasifiers for heat and power. A global review. World Bank technical paper 296. Washington, DC http://documents.worldbank.org/curated/ en/583671468769505568/Small-scale-biomass-gasifiers-for-heat-and-power-a-global-review

Tag AT, Duman G, Ucar S, Yanik J (2016) Effects of feedstock type and pyrolysis temperature on potential applications of biochar. J Anal Appl Pyrolysis 10:200-206

Tan Y (2013) Feasibility study on solid waste to energy technological aspects. UC Berkeley College of Engineering, Fung Institute for Engineer-ing Leadership

Tan X, Liu Y, Zeng G, Wang X, Hu X, Gu Y, Yang Z (2015) Application of biochar for the removal of pollutants from aqueous solutions. Chemosphere 125:70-85

Teella A, Huber GW, Ford DM (2011) Separation of acetic acid from the aqueous fraction of fast pyrolysis bio-oils using nanofiltration and reverse osmosis membranes. J Membr Sci 378:495-502

Tewfik SR, Sorour MH, Abulnour AMG, Talaat HA, El Defrawy NM, Farah JY, Abdou IK (2011) Bio-oil from rice straw by pyrolysis: experimental and techno-economic investigations. J Am Sci 7(2):59-67

Thammasom N, Vityakon P, Lawongsa P, Saenjan P (2016) Biochar and rice straw have different effects on soil productivity, greenhouse gas emission and carbon sequestration in Northeast Thailand paddy soil. Agric Nat Res 50:192-198

Tripathi M, Sahu JN, Ganesan P (2016) Effect of process parameters on production of biochar from biomass waste through pyrolysis: a review. Renew Sust Energ Rev 55:467-481

Uchimiya M, Bannon DI, Wartelle LH, Lima IM, Klasson KT (2012) Lead retention by broiler litter biochars in small arms range soil: impact of pyrolysis temperature. J Agric Food Chem 60(20):5035-5044. https://doi.org/10.1021/jf300825n

Ukaew S, Schoenborn J, Klemetsrud B, Shonnard DR (2018) Effects of torrefaction temperature and acid pretreatment on the yield and quality of fast pyrolysis bio-oil from rice straw. J Anal Appl Pyrolysis 129:112-122

Wang S, Gu Y, Liu Q, Yao Y, Guo Z, Luo Z, Cen K (2009) Separation of bio-oil by molecular distillation. Fuel Process Technol 90:738-745

Wang Z, Lin W, Song WL, Du L, Li ZJ, Yao JZ (2011) Component fractionation of wood-tar by column chromatography with the packing material of silica gel. Chin Sci Bull 56(14):1434-1441 
Wu W, Yang M, Feng Q, McGrouther K, Wang H, Lu H, Chen Y (2012) Chemical characterization of rice straw-derived biochar for soil amendment. Biomass Bioenergy 47:268-276

Yang SY, Wu CY, Chen KH (2011) The physical characteristics of bio-oil from fast pyrolysis of rice straw. Adv Mater Res 328-330:881-886

Yang S, Xiao Y, Sun X, Ding J, Jiang Z, Xu J (2019) Biochar improved rice yield and mitigated $\mathrm{CH}_{4}$ and $\mathrm{N}_{2} \mathrm{O}$ emissions from paddy field under controlled irrigation in the Taihu Lake region of China. Atmos Environ 200:69-77

Young GC (2010) Municipal solid waste to energy conversion processes: economic, technical, and renewable comparisons. Wiley, Hoboken

Yun-Feng Y, Xin-hua H, Ren G, Hong-Liang M, Yu-Sheng Y (2014) Effects of rice straw and its biochar addition on soil labile carbon and soil organic carbon. J Integr Agric 13(3):491-498

Zafar S (2018). Rice straw as bioenergy resource. https://www.bioenergyconsult.com/ rice-straw-as-bioenergy-resource

Zeng F, Liu W, Jiang H, Yu H-Q, Zeng RJ, Guo Q (2011) Separation of phthalate esters from biooil derived from rice husk by a basification-acidification process and column chromatography. Bioresour Technol 102:1982-1987

Zhang J, Liu J, Liu R (2015) Effects of pyrolysis temperature and heating time on the biochar obtained from the pyrolysis of straw and lignosulfonate. Bioresour Technol 176:288-291

Open Access This chapter is licensed under the terms of the Creative Commons Attribution 4.0 International License (http://creativecommons.org/licenses/by/4.0/), which permits use, sharing, adaptation, distribution and reproduction in any medium or format, as long as you give appropriate credit to the original author(s) and the source, provide a link to the Creative Commons licence and indicate if changes were made.

The images or other third party material in this chapter are included in the chapter's Creative Commons licence, unless indicated otherwise in a credit line to the material. If material is not included in the chapter's Creative Commons licence and your intended use is not permitted by statutory regulation or exceeds the permitted use, you will need to obtain permission directly from the copyright holder.

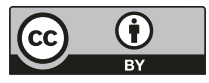

